\title{
Rett Syndrome: Review of Biological Abnormalities
}

\author{
Henry G. Dunn and Patrick M. MacLeod
}

\begin{abstract}
The Rett syndrome (RS) is a peculiar, sporadic, atrophic disorder, almost entirely confined to females. After the first six months of life there is developmental slowing with reduced communication and head growth for about one year. This is followed by a rapid destructive stage with severe dementia and loss of hand skills (with frequent hand wringing), apraxia and ataxia, autistic features and irregular breathing with hyperventilation. Seizures often supervene. Subsequently there is some stabilization in a pseudo-stationary stage during the preschool to school years, associated with more emotional contact but also abnormalities of the autonomic and skeletal systems. After the age of 15-20 years, a late motor deterioration occurs with dystonia and frequent spasticity but seizures become milder. RS has generally been considered an X-linked disorder in which affected females represent a new mutation, with male lethality. Linkage studies suggested a critical region at Xq28. In 1999, mutations in the gene $M E C P 2$ encoding X-linked methyl cytosine-binding protein 2 (MeCP2) were found in a proportion of Rett girls. This protein can bind methylated DNA. Analyses are leading to much further investigation of mutants and their effects on genes. Neuropathological and electrophysiological studies of RS are described. Description of neurometabolic factors includes reduced levels of dopamine, serotonin, noradrenaline and choline acetyltransferase (ChAT) in brain, also estimation of nerve growth factors, endorphin, substance $\mathrm{P}$, glutamate and other amino acids and their receptor levels. The results of neuroimaging are surveyed, including volumetric magnetic resonance imaging (MRI) and positron emission tomography (PET).
\end{abstract}

RÉSUMÉ: Le syndrome de Rett: revue des anomalies biologiques. Le syndrome de Rett (SR) est une maladie atrophique sporadique singulière qui touche presque exclusivement les filles. Après les premiers six mois de la vie, l'enfant présente un ralentissement du développement accompagné d'une diminution de la communication et de la croissance de la tête pendant à peu près un an, suivi d'une phase de destruction rapide avec démence sévère et perte de la dextérité manuelle (avec de fréquents épisodes de torsion des mains), de l'apraxie et de l'ataxie, des manifestations autistiques et une respiration irrégulière avec hyperventilation. Des crises convulsives s'ajoutent souvent au tableau. Par la suite, il y a une certaine stabilisation ou phase pseudo-stationnaire pendant la période préscolaire et scolaire, associée à plus de contacts émotifs mais aussi à des anomalies des systèmes autonome et squelettique. Après l'âge de 15 ou 20 ans, on observe une détérioration motrice accompagnée de dystonie et fréquemment de spasticité, et les crises convulsives s'atténuent. En général, on a considéré que le SR est une maladie liée à l'X où les filles atteintes sont porteuses d'une nouvelle mutation, une telle mutation étant léthale chez les garçons. Des études de liaison ont indiqué une région critique au niveau de Xq28. En 1999, des mutations dans le gène MECP2, le gène de la protéine de liaison de la méthyl cytosine2 lié au X (MECP2), ont été identifiées chez des filles porteuses du SR. Cette protéine peut lier l'ADN méthylé. Ces analyses ont mené à des investigations plus poussées des mutants et de leurs effets sur les gènes voisins. Des études neuropathologiques et électrophysiologiques du SR sont décrites. Parmi les facteurs neurométaboliques, on fait état de niveaux abaissés de dopamine, de sérotonine, d'adrénaline et de choline acétyltransférase (ChAT) dans le cerveau, et on rapporte également une évaluation des facteurs de croissance nerveux, des endorphines, de la substance $\mathrm{P}$, du glutamate et d'autres acides aminés et des niveaux de leurs récepteurs. Les résultats de la neuroimagerie sont présentés, incluant la RMN volumétrique et le PET scan.

Can. J. Neurol. Sci. 2001; 28: 16-29

Although Andreas Rett, an Austrian pediatrician, first described a peculiar syndrome of brain atrophy in childhood in $1966,{ }^{1}$ and a Japanese group independently reported three similar cases in $1978,{ }^{2}$ the condition was not brought to the attention of the English-speaking world until 1983, when Hagberg and his co-authors $^{3}$ published a report of 35 cases in the Annals of
From the Division of Neurology, British Columbia's Children's Hospital, Vancouver, BC,Canada.

Received March 12, 2000. Acceptedin finalform September 26, 2000. Reprint requests to: HGDunn, Division of Neurology, British Columbia's Children's Hospital, 4480 Oak Street, Vancouver, BC,Canada V6H 3V4 
Neurology, as a progressive syndrome of autism, dementia, ataxia and loss of purposeful hand use in girls: Rett's syndrome (RS). Further studies confirmed that the disease was practically confined to girls and, in 1986, Hagberg and Witt-Engerström ${ }^{4}$ suggested a staging system for describing the impairment profile with increasing age. According to this system the four clinical stages in the classical form of the disease were:

I. Early onset deceleration stage at 6-18 months, with developmental stagnation, decelerating head growth, reduced communication and eye contact, and hypotonia.

II. Rapid destructive stage at one to three years, with severe dementia, loss of hand skills and frequent hand wringing, autistic features, loss of expressive language, and possible onset of seizures.

III. Pseudo-stationary stage in preschool to school years with persistent severe mental retardation but amelioration of autistic features, persistent hand stereotypies, ataxia and apraxia, persistence of seizures, irregular breathing and hyperventilation while awake, bruxism and early scoliosis.

IV. Late motor deterioration stage from the teen years, with progressive scoliosis, combined upper and lower motor neuron signs, trophic disturbance of feet but improved eye contact and reduced seizure frequency.

This staging system was adopted by an international RS Diagnostic Criteria Work Group in $1988 .^{5}$ The group established necessary diagnostic criteria for the disease, including an apparently normal prenatal and perinatal period, normal psychomotor development through the first six months and normal head circumference at birth. They further listed supportive criteria like breathing dysfunction, breath-holding spells, intermittent hyperventilation, and periodic apnea during wakefulness. They also described EEG abnormalities and growth retardation.

Among exclusion criteria, this Work Group mentioned evidence of intrauterine growth retardation, organomegaly, retinopathy or optic atrophy, microcephaly at birth, evidence of perinatal brain damage and existence of identifiable metabolic or other progressive neurological disorder.

In 1994 Hagberg and Skjeldal ${ }^{6}$ defined inclusive and supportive criteria for atypical Rett variants ("forme fruste") at the age of ten or more years. It was postulated that the girls should have mental retardation of unexplained origin and at least three of six primary criteria like loss of acquired fine finger skills in early childhood, hand stereotypies like wringing and deceleration of head growth by 2 SD. In addition, these girls were expected to have at least five out of $11 \mathrm{RS}$ supportive criteria, like breathing irregularities, grinding of teeth and intensive eye communication. The variants also included girls with unusually preserved speech as described by Zappella. ${ }^{7}$

Three other clinical features which have recently been emphasized in Rett girls are osteopenia, ${ }^{8,9}$ abnormalities of bone development ${ }^{10}$ and also difficulties in swallowing and gastroesophageal motility. ${ }^{11}$ In this connection there has been increasing concern with "bloating" and abdominal distention in $\mathrm{RS}^{12}$ partly from swallowing air during breath-holding, and occasionally from gulping during hyperventilation. Even with seemingly adequate feeding the girls' weight gain may be slow, particularly in the first decade. Gastrostomy feeding may then usefully be added.
Prevalence studies from Sweden and Scotland ${ }^{13-15}$ showed that RS occurred about once in 10,000-15,000 girls, i.e. more commonly than phenylketonuria, and thus represents one of the more frequent causes of more than mild mental retardation in girls.

\section{GENETICS}

Most of the cases of RS are isolated in their families, apart from identical twins being affected. However, in Sweden it was noted that affected children tended to cluster in certain areas and frequently had some common ancestry. ${ }^{16}$ Often milder "forme fruste" cases came from the same "Rett areas" as classical RS girls. Akesson et $\mathrm{al}^{17}$ suspected that transmission might start with a premutation which over generations could result in a full mutation with greater clinical severity. Similar clustering of cases was described in Italy, ${ }^{18}$ Hungary, ${ }^{19}$ Australia $^{20}$ and Norway. ${ }^{21}$

Rett syndrome has generally been considered to be an $\mathrm{X}$ linked dominant disorder in which every case represented a new mutation, with male lethality. However, there was no such gross deficiency of males among the siblings of Rett girls as might be expected. In 1992, Witt-Engerström and Forslund ${ }^{22}$ reported RS characteristics in a girl who was the only known offspring of a patient with RS. In males with clinical features of RS, abnormalities of the XY chromosomes have to be excluded, particularly Klinefelter syndrome (even mosaicism). ${ }^{23,24}$ Nonrandom chromosome $\mathrm{X}$ inactivation may also be involved. Neonatal encephalopathy in two boys in families with recurrent RS was described by Schanen et $\mathrm{al}^{25}$ and another such case documented by Wan et $\mathrm{al}^{26}$ was the hemizygous son of a woman who had incoordination, mild learning disability and skewed $\mathrm{X}$ inactivation and had both a sister and a daughter with classical RS. Linkage studies with detailed genotyping of $\mathrm{X}$ chromosomes were used in rare cases of other family members being affected. ${ }^{27-29}$ This permitted exclusion mapping of $\mathrm{X}$ chromosome regions where the probands had inherited different alleles. Such linkage studies suggested a critical region at Xq28, the terminal part of the long arm of the X-chromosome. ${ }^{30-33}$

In 1999, Amir and other experienced investigators ${ }^{34}$ then found several mutations in the gene $M E C P 2$ encoding the $\mathrm{X}$ linked methyl-CpG binding protein $2(\mathrm{MeCP} 2)$ in a proportion of Rett patients. This protein can bind methylated DNA and, when it is mutated, transcriptional silencing of some genes may be unduly reduced. This may result in abnormal chromatin assembly or remodelling with consequent epigenetic effects on expression of one or more genes that are themselves not mutated. ${ }^{35}$ The molecular changes leading to the decline of the patients in Stages I and II could be explained by the overexpression of some genes that govern the development of the brain. Hendrich ${ }^{36}$ refers to only one other disease with a somewhat similar etiology, namely the ICF syndrome (immunodeficiency, centromere instability and facial anomalies), which is a rare, autosomal recessive disorder with low immunoglobulin levels and abnormal DNA methylation. ${ }^{37}$ Genetic mapping of the ICF locus to the long arm of chromosome 20 led to the gene encoding methyltransferase DNMT3ß in the same region. So far nine different mutations in the DNMT3ß protein have been identified. Its function appears 


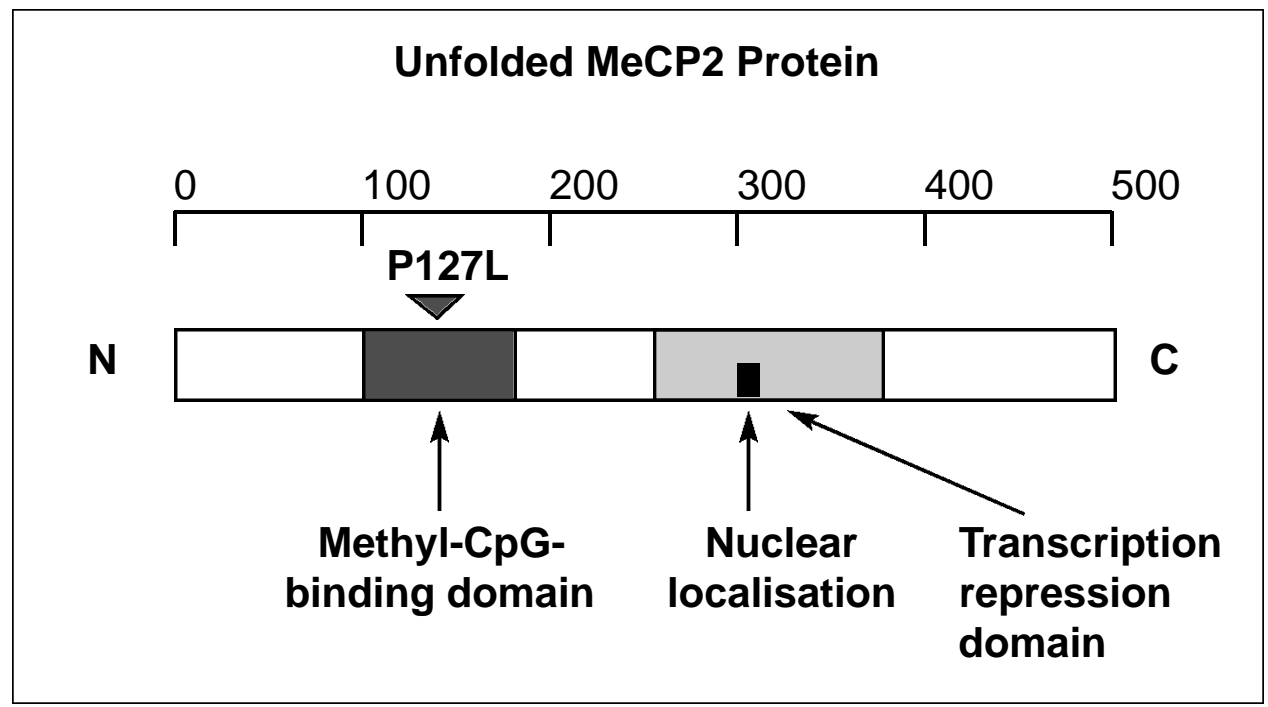

Figure: A diagram of the MeCP2 protein with three major functional domains. The arrowhead indicates the location of a point mutation in the methyl binding domain. A single amino acid substitution at this position prevents the protein from binding with previously transcribed methylated DNA. P127Lis one of our own patients.

to be to methylate DNA, whereas MeCP2 binds to methylated DNA. The mutations of $\mathrm{MeCP} 2$ are being investigated actively.

The MeCP2 protein has a domain (MBD) that binds to methylated $\mathrm{CpG}$ dinucleotides. Another domain, defined as transcription repression domain (TRD) interacts with a protein complex containing histone deacetylases that mediate transcription repression by modification of chromatin structure and may also have nuclear localization. The Figure shows these domains and the appropriate placement of one of our patients, classified as P127L in MBD. Several groups of investigators have analyzed their RS cases with respect to these domains and have also divided the mutations into missense, nonsense, truncating and frame shift. About $75-80 \%$ of classical RS patients have been shown to have mutations in MECP $2 .{ }^{38-40}$ Amir and her colleagues at Baylor University ${ }^{38}$ also examined X chromosome inactivation and found in the $9 \%$ where it was nonrandom, it was associated with milder phenotypes. Usually there was no abnormality in the parents.

At the World Congress on Rett Syndrome 2000 in Nagano, Japan, Uta Francke ${ }^{40 a}$, of Stanford University, USA, reviewed the spectrum of $M E C P 2$ mutations in RS. She noted that about 66 different mutations in the $M E C P 2$ gene have been reported, half of which are single occurrences. A third of them lead to single amino acid substitutions. These missense mutants cluster in the MBD. Six missense mutations affect the TRD and may prevent interaction with the silencing complex. Truncating mutations make up about two-thirds. They are either nonsense mutations or insertions/deletions that lead to frame shifts and premature stop codons. The latter group ranges from single nucleotide insertions or deletions to an array of rearrangements in the genomically unstable $\mathrm{C}$-terminal region that comprise up to 170 nucleotides and are often complex insertions/deletions. The commonest missense mutations were R106W, R133C, T158M and R306C, while the most frequent nonsense mutations were R168X, R255X, R270X and R294X. In RS mosaicism, defects vary with the mutations and the mother may be asymptomatic.

Cheadle and his colleagues in Wales ${ }^{41}$ also correlated mutations in the gene $M E C P 2$ with the features of RS. Mutations were sought in 48 females with classical sporadic RS, seven families with possible familial RS and five sporadic females with features suggestive but not diagnostic of RS. In all cases, long distance polymerase chain reaction coupled with long-read direct sequencing was employed to investigate the entire $M E C P 2$ gene coding region. Mutations were identified in 44/55 (80\%) unrelated classical sporadic and familial RS patients but in only $1 / 5(20 \%)$ of sporadic cases with suggestive but nondiagnostic features of RS. Twenty-one different mutations were identified, and 14 of these were novel. Nine recurrent mutations were characterized in a total of 33 unrelated cases. Significantly milder disease was noted in patients carrying missense mutations as compared with those with truncating mutations and milder disease was associated with late, as compared to early, truncating mutations.

At the World Congress on Rett Syndrome 2000, a keynote speech by Nan et $\mathrm{al}^{42}$ from Edinburgh referred to RS research in mice. They stated that methylation of DNA is essential for development in the mouse and plays an important role in inactivation of the $\mathrm{X}$-chromosome and genomic imprinting. Work on animals, plants and fungi leaves little doubt that gene silencing is a major biological consequence of DNAmethylation. MeCP2 consists of a single polypeptide that contains both a MBD and a TRD. Methyl-CpG binding domain binds to a single symmetrically methylated $\mathrm{CpG}$ site flanked by nonspecific sequences of at least six base pairs on each side and is responsible for localization of the protein to chromosomes. Spectroscopic studies reveal that the MBD adopts a wedgeshaped structure, in which an N-terminal 4-stranded anti-parallel B-sheet forms one face of the wedge, while the other face is formed mainly by a C-terminal helical region. The TRD interacts 
with $\operatorname{Sin} 3$, which is known to be part of a multi-protein complex that includes histone deacetylases. These enzymes presumably participate in chromatin modification and in MeCP2-mediated transcriptional repression.

It is speculated that abnormal gene expression in Rett patients leads to dysfunction of the central nervous system. To study the functional role played by $\mathrm{MeCP} 2$, the Mecp 2 gene was earlier disrupted in mouse embryonic stem cells by conventional homologous recombination. Chimaeric embryos, derived from the mutant stem cells, failed to develop normally. In order to construct a mouse model of RS the authors have recently created a deletable allele at the Mecp2 locus. The phenotype of mice lacking MeCP2 may have relevance as a model of RS.

In discussion, Dr. Van den Veyver noted that these mutant mice show tissue-specific imprinting, and modifier genes at other loci may affect the severity of the disease as in humans. Male survival is variable, with possible regulatory mutations, and sudden death may occur. Functional analysis of mutations in vivo and in vitro is needed in both mice and humans and truncating mutations are of particular interest. In human patients, $\mathrm{X}$-chromosome inactivation should be recorded regularly. Nuclear involvement also requires longitudinal study. With respect to the biphasic clinical course with early acute deterioration and subsequent plateau, relevant measurements might include diminished cholinergic neurons and synaptophysin, as well as dopamine, serotonin and glutamate and their receptors. It also remains of interest whether synaptic proliferation in the forebrain is reduced by inadequate brain stem activity or by local conditions in the cortex.

Finally, there appeared to be general agreement that an international committee should formulate standard clinical records for the common $\mathrm{MeCP} 2$ mutations in $\mathrm{RS}$ cases and should check X-chromosome inactivation, electroencephalograms and suitable brain scans with assessment of serotonergic, dopaminergic and noradrenergic activity and their receptors as well as glutamate and other relevant levels. Christodoulou and his colleagues in Australia ${ }^{43}$ have offered to be curators of such a mutation database. A register of autopsy studies and controls should also be established. Meanwhile, demonstration of mutations in MeCP2 can assist in the early diagnosis of RS and, with research, might even lead to preventive gene treatment.

Neuropathological studies have shown no consistent site of gross neuronal degeneration and no evidence of abnormal neuronal migration. However, the average head circumference of girls with RS at birth is already slightly lower than that of normal control children of the same gestational age $\mathrm{at}^{44}$ and slowing of head growth becomes definite from the age of about three months. Jellinger et $\mathrm{al}^{45}$ found that in nine Rett girls aged three to 17 years, brain weight was decreased to $66 \%-88 \%$ of expected values for the age. These authors also noted hypopigmentation of the substantia nigra due to decrease in the number of melanin granules per neuron. Bauman et $\mathrm{al}^{46}$ observed a global decrease in the size of individual neurons in RS, associated with increased packing density. Oldfors et $\mathrm{al}^{47}$ described cerebellar hypoplasia and progressive atrophy (often focal) with astrocytic gliosis and loss of Purkinje cells in older patients.

In 1994, Armstrong ${ }^{48}$ summarized the neuropathology of RS and mentioned that the selectivity of the volume decrease in the Rett brain had been confirmed with Golgi technique. Dendritic trees had been found to be significantly diminished in the following areas of Rett brains:

- the basal branches of pyramidal neurons in layers III and V of prefrontal cortex;

- the basal branches of pyramidal neurons in layers III and V of the motor cortex and apical branches of pyramidal neurons of layer V;

- the basilar branches of layer IV neurons of the subicular cortex.

In general, the decrease in brain size was most marked in the frontal lobe, the caudate and midbrain. Armstrong commented that there was no evidence of a demyelinating condition in the white matter and the only lesions suggestive of degeneration had been reported in the cerebellum, spinal cord and peripheral nerves of some older patients; these might well be secondary to motor disability. ${ }^{49-51}$ Kitt and Wilcox ${ }^{52}$ further reported preliminary results showing abnormalities in the substantia nigra (pars compacta), including decreased numbers of neurons, ubiquitin-stained neuronal inclusion bodies, decreased immunostaining for transmitter markers, and histochemical evidence for cell death within fragmented intranucleosomal DNA. In 1997, Belichenko et al ${ }^{53}$ compared various neocortical areas from four Rett females, aged 16-24 years, to similar areas from patients with resistant partial epilepsy, infantile autism and two normal controls. Special techniques and laser scanning in the affected focal areas showed greatly thinned dendrites with reduced spines in the Rett girls. The authors concluded that the RS might best be explained by postnatal deficiency of synaptogenic development but the basic defect remained unknown.

A significant proportion of $\mathrm{RS}$ infants exhibit minor abnormalities in the newborn period like hypotonia, poor sucking or abnormal postures, ${ }^{54-56}$ and this was recently confirmed in Australian studies. ${ }^{44}$ Pathological findings like reduced melanin granules in the zona compacta of the substantia nigra $^{45}$ and absence of expected simplified convolutions in inferior olivary nuclei (which should normally be established by 28-32 weeks'gestation), ${ }^{46}$ support the concept that the disease is established before birth.

\section{ELECTROPHYSIOLOGY}

The electroencephalogram (EEG) in RS is usually clearly abnormal except in the initial stage. It tends to be diffusely slow and frequently shows focal or generalized epileptiform abnormalities. Progressive deterioration was first noted by Hagberg et $\mathrm{al}^{3}$ in their first report on the RS. Glaze et $\mathrm{al}^{57}$ correlated the EEG with clinical staging. In Stage II the EEG is frequently characterized by slowing of background rhythms, rare focal spike or sharp wave discharges while awake, and progressive loss of sleep characteristics like spindles and vertex transients. Focal spike and sharp wave discharges typically occur in the central-parietal regions. In Stage III, further slowing is noted with appearance of delta waves and generalized spikewave pattern may first be seen during sleep and later also during awake states as in the Lennox-Gastaut syndrome. In Stage IV, the EEG pattern may improve to some extent, with fewer focal epileptiform discharges, some faster frequencies and frequent fronto-central theta activity but still shows generalized slow 
spike-wave activity during non-random eye movement (NREM) sleep. These findings were confirmed in our Children's Hospital ${ }^{58,59}$ where amino acids and biogenic amine metabolites were also assessed in spinal fluid with normal results. Central spikes tend to decrease after the age of 10 years; they may be blocked by passive movements of the opposite fingers. ${ }^{60}$

Elian and Rudolf ${ }^{61}$ reviewed 44 EEGs of 16 girls with RS. Their ages ranged from eight months to 20 years. Eight girls showed a pseudo-periodic pattern, as short bursts of highamplitude slow waves were associated with apnoea and loweramplitude faster rhythms with normal breathing or with hyperventilation. The authors also noted abnormal breathing solely in the waking state and suggested that the abnormal respirations were voluntary.

In 1997, Niedermeyer and his colleagues ${ }^{62}$ commented on the $^{2}$ unusual theta rhythms over the central regions in the RS. When these were noted in the waking state, the localization at the vertex and in the central region and the blocking responses to active or passive movements suggested a slow equivalent of Rolandic $\mu$ rhythm. When they occurred during sleep, rhythmical theta was either Rolandic or more diffuse, sometimes seen independently with central spikes. The prominent rhythmical $4-5 / \mathrm{sec}$ or $5-6 / \mathrm{sec}$ activity and its relationship to Rolandic $\mu$ suggested a dysfunction of the motor cortex in RS.

Glaze et $\mathrm{al}^{63}$ evaluated the hypothesis that many events classified as seizures in RS represented other paroxysmal, nonepileptic events. Video/polygraphic EEG monitoring in 82 Rett females, aged 2-30 years, showed that 55 patients $(67 \%)$ had had seizures and 52\% were receiving anticonvulsants, all with abnormal EEGs. The frequency of epileptiform findings ranged from $60 \%$ of patients in Stage IV to $97 \%$ of patients in clinical Stage III. However, during monitoring, electrographic seizures were recorded in only 13 patients (16\%), and there were many pseudo-seizures. Also, Guerrini and his colleagues ${ }^{64}$ noted the frequency of cortical reflex myoclonus in RS. They observed such myoclonus in nine out of ten Rett patients aged three to 20 years. Multifocal, arrhythmic and asynchronous jerks mainly involved the distal part of limbs. Somatosensory evoked potentials were enlarged.

Yamanouchi et al ${ }^{65}$ studied visual and somatosensory evoked potentials in nine patients with RS and compared giant potentials with those in photosensitive progressive myoclonus epilepsy, noting significant differences.

Transcranial magnetic stimulation has also been used in Rett girls. Heinen et $\mathrm{al}^{66}$ investigated 31 patients, aged two to 38 years, and compared them with 112 healthy control persons. While peripheral conduction time showed no difference from the controls, the mean central conduction time was shorter in the younger patients with RS and particularly in the youngest. Nezu et $\mathrm{al}^{67}$ performed magnetic stimulation in three Rett patients aged four, six and 13 years and compared the central motor conduction time (CMCT) in age-matched normal children on stimulation of the relaxed first dorsal interosseous muscle. CMCT in the two Stage III cases was significantly short, while in the older Stage IV girl it was markedly but not significantly short with progressive spastic paresis. CMCT shortening was consistent and was again thought to imply cortical hyperexcitability.

On the other hand, in older Rett females in Stage IV brain stem auditory evoked responses and somatosensory responses evoked from median, tibial and sural nerves may show prolonged latency as well as reduced amplitude of the cortical response. Involvement of subcortical structures, brain stem and spinal cord has been suspected. ${ }^{50,68,69}$

\section{NEUROMETABOLIC FACTORS}

Nomura, Segawa and their Japanese co-workers ${ }^{70-72}$ have long suspected that the motor symptoms of RS, with abnormal muscle tone, posture and locomotion as well as stereotyped movements, originated in the brain stem and midbrain and affected the monoaminergic systems, particularly inadequate formation of noradrenaline, serotonin and dopamine. Polysomnographic examinations ${ }^{73,74}$ also revealed prolonged daytime sleep with abnormally persistent random eye movement (REM) sleep and irregular periodicity. Accordingly it was suspected that the raphe nuclei and locus coeruleus were involved initially, followed by the basal ganglia, with possible post-synaptic supersensitivity of the dopaminergic system in the later stages. Interestingly, others ${ }^{75}$ have shown that catecholamine antagonists given to newborn rats reduce endogenous noradrenaline in cerebral cortex and produce decreased length and branching of basolateral dendrites of pyramidal cells in layers $\mathrm{V}$ and III, most abundantly in frontal and cingulate cortex. Also, dopamine fibers distributed in the cerebral hemisphere do project preferentially to the frontal and temporal cortex, so that a deficiency of their influence might account for the selective regional decrease in brain volume in RS. On the other hand, Perry et $\mathrm{al}^{76}$ examined the spinal fluid of five children with RS at the ages of 2.5 to 15 years and found no significant abnormality in the level of metabolites of noradrenaline, dopamine or serotonin. In addition, concentrations of gamma-aminobutyric acid (GABA) and a large number of other amino acids were normal. Lekman et $\mathrm{al}^{77}$ had similar normal findings with respect to biogenic amine metabolites in the spinal fluid of girls with RS. However, this group of investigators ${ }^{78}$ also examined selected postmortem brain regions from four RS patients, aged 12-30 years, and found a $50 \%$ or greater reduction in the level of dopamine, serotonin and noradrenaline and their respective metabolites homovanillic acid and 5-hydroxyindole acetic acid (but not hydroxymethoxyphenylglycol) in the substantia nigra from the two older patients, while the youngest girl of 12 years had normal or near normal levels. A generalized deficiency of dopamine was not observed. Wenk et $\mathrm{al}^{79}$ reported that neurochemical assays of postmortem brains in three RS patients and controls in 12 cortical and subcortical regions showed decreased levels of dopamine, norepinephrine, serotonin and their metabolites in most brain regions as compared to a Down syndrome patient and the control subjects. There was also a reduction in the cortical level of choline acetyl transferase (ChAT), the enzyme involved in the liberation of acetyl choline at nerve terminals. In a further publication in 1991, Wenk and his colleagues ${ }^{80}$ reported a preliminary postmortem study that compared the levels of endogenous biogenic amines and selected neurotransmitter receptors in five cases of RS and six normal controls. The level of ChAT activity was reduced in several cortical and subcortical regions. Endogenous levels of dopamine in the superior frontal 
and superior temporal gyri, occipital cortex and putamen were reduced. The reduction of ChAT in assays of post mortem brain from RS patients was confirmed by Johnston et al ${ }^{81}$ who also reported that in RS the cell packing density within grey matter is increased, while the total number of neurons is relatively normal, except for selected populations such as the nucleus basalis of Meynert and the substantia nigra. These authors also showed that in rodents, early postnatal injury to cholinergic pathways can cause permanent disruption of developing cholinergic neurons and a behavioural disorder on maze testing. This has recently been confirmed by Berger-Sweeney ${ }^{82}$ who studied the effects of neonatal basal forebrain lesions on cognition in mice and rats.

In 1995 , Wenk ${ }^{83}$ further analyzed postmortem material from 11 Rett patients (age 4-30 years) and ten normal female controls. He showed that dopamine reuptake sites had a normal density in cingulate and midfrontal gyri of the patients but were decreased within the caudate nucleus and putamen. This suggested that in the midfrontal and cingulate cortex, dopaminergic neuronal activity might show a compensatory increase for fewer terminals containing less dopamine in the basal ganglia. In the following year, the same author ${ }^{84}$ reported further studies in the brains of 12 RS patients and 14 normal female controls. Endogenous levels of dopamine, its metabolite homovanillic acid, dopamine reuptake sites and dopamine type 2 receptors did not differ significantly between RS and control girls in any brain region examined. Hence the data supported the hypothesis that dopaminergic neuronal function may be "relatively normal" in RS. This clearly required further analyses, particularly by positron emission tomography (PET) scans, as described later in this article.

Kaufmann and his associates ${ }^{85}$ studied the relationship between cholinergic deficit and dendritic protein expression in RS. They found that dendritic development was characterized by the sequential expression of cytoskeletal proteins whose levels remain relatively stable in adult life. With quantitative immunoblotting they noted that in RS there is a reduction in microtubule-associated protein (MAP) linked to early dendritic development, including MAP-5 and MAP-2. By contrast, in Down syndrome there is a relative generalized increase in dendritic proteins. Mice with basal forebrain lesions at birth, which transiently decrease cholinergic innervation to the cortex, showed reductions in MAP-2 in adulthood resembling those in RS. Thus dendritic anomalies in RS appeared to represent disturbances in early cortical differentiation, and cholinergic deficit may play a critical role in their causation. The significance of MAPs is discussed further by Naidu. ${ }^{86}$

Nerve growth factors in cholinergic and monoaminergic pathways are influenced by neurotrophins which affect maintenance of function in neurons. This has been demonstrated with nerve growth factor (NGF) in developing cholinergic neurons ${ }^{87}$ and with brain-derived neurotrophic factor (BDNF) and glial cell line-derived neurotrophic factor in the maintenance of dopaminergic neurons ${ }^{88}$. In 1996, Lappalainen et al ${ }^{89}$ reported finding low levels of NGF in the cerebrospinal fluid (CSF) of children with RS. Vanhala et $\mathrm{al}^{90}$ further noted that, whereas levels of brain-derived neurotrophic factor and glial cell linederived neurotrophic factor in spinal fluid of Rett girls were below the limit of sensitivity of the methods used, serum levels of NGF and BDNF did not differ from control values. This seemed to indicate low levels of nerve growth factor in the central nervous system. In 1999, Riikonen and Vanhala ${ }^{91}$ compared the levels of growth factors in autism and RS, using enzyme-linked immunosorbent assay. They found mainly normal CSF NGF in autism and low to negligible values in RS, consistent with a different pathogenesis in the two diseases. However, Wenk and Hauss-Wegrzyniak ${ }^{92}$ performed postmortem analyses on the basal forebrain and ventral globus pallidus from ten RS patients (age range 4-35 years) and compared them to the findings in 14 age-matched control girls. Surprisingly, cortical levels of NGF were normal in RS girls, and the number of neurons within the basal forebrain expressing the p75 low-affinity receptor for NGF was unchanged. In contrast, the number of ChAT-positive neurons was significantly decreased. The authors suggest that normal amounts of NGF are available for binding to the receptor and for retrograde transport to forebrain cholinergic cells but the neurons do not respond by producing the ChAT protein which is necessary for the production of acetyl choline. In this connection it has been stated that augmentation of cholinergic function by means of perinatal choline treatment may enhance cognitive performance in animals. ${ }^{93}$ Recent information reveals complex interactions between the cholinergic basal forebrain afferents and the neurotrophin family. The clarification of this relationship is likely to be of clinical relevance in RS.

Autonomic function. As mentioned above, Japanese workers have long suspected a deficiency of noradrenaline as one of the abnormalities in infants with RS. Nomura and her colleagues ${ }^{70,71}$ also noted abnormal twitching movements during REM sleep bursts, atonia during NREM sleep, and akinesia on attempted walking which could be attributed to hypofunction of noradrenaline, e.g. in the brain stem (?locus ceruleus). Recently Nomura et $\mathrm{al}^{94}$ also studied sympathetic skin responses in Rett girls on electrical stimulation and found that some had absence of these responses, while others demonstrated asymmetric parameters which suggested involvement of the autonomic system at a peripheral level and possible influences from higher centers. The asymmetry correlated with the side of scoliosis but not with handedness.

Julu et al ${ }^{95}$ reported their studies of autonomic activity in 17 Rett girls and eight controls. Breathing movements were monitored using a plethysmograph around the chest. Sympathetic activity was monitored by measuring blood pressure, and cardiac parasympathetic activity was measured by using the cardiac response to baroreflex. Mean arterial blood pressure was $78 \pm 4.33 \mathrm{~mm} \mathrm{Hg}$ in Rett girls, within the control value of $94.6 \pm 6.4 \mathrm{~mm} \mathrm{Hg}$, and cardiac vagal tone in the RS girls was $65 \%$ lower than in their age-matched controls, equal to reported levels in the newborn. Each Rett girl had at least six types of breathing dysrhythmias. Oscillations and rebounds in heart rate and blood pressure contrasted with smooth changes in control girls. Cardiac vagal tone was invariably withdrawn at the height of sympathetic activity during both hyperventilation and breath holding, leading to sympathovagal imbalance with a risk of cardiac arrhythmia and possibly sudden death. ${ }^{96,97}$ It has also been noted that corrected Q-T intervals in Rett girls are significantly longer and that heart rate variability is reduced in comparison to controls. ${ }^{98,99}$

At a workshop on autonomic function in RS in Sweden, ${ }^{100}$ 
data presented by various authors supported the concept that the autonomic system is immature in these girls, with overactive sympathetic and diminished vagal activity. Dahlström ${ }^{100}$ noted the small, cold, bluish feet. In a case described by Ljungberg and Hagberg ${ }^{101}$ the colour, temperature and cavus configuration of one foot were normalized after an inadvertent unilateral sympathectomy during scoliosis surgery. Further, Dahlström pointed out that chronic constipation with sluggish bowel in RS may also be a sign of autonomic dysfunction. Esophageal reflux and esophagitis are commonly seen and may benefit from button gastrostomy, as in one of our patients. ${ }^{11}$

Julu and his colleagues ${ }^{100}$ reported that the cardio-respiratory instability in RS suggested medullary serotonergic dysfunction. On treatment with Buspirone, a serotonin receptor $1_{\mathrm{A}}$ agonist 5$20 \mathrm{mg} /$ day, one Rett girl aged 13 years had a greatly reduced index of protracted inspirations and normal breathing increased. The authors suggested that the medulla is functionally immature in $\mathrm{RS}$ and that stimulation of serotonin receptor $1_{\mathrm{A}}$ might usefully be combined with drugs increasing GABAergic inhibition. Armstrong et $\mathrm{al}^{102}$ reported that fresh frozen brain stems from three Rett patients, five infants and three mature control cases had been studied with autoradiography utilizing $\left[{ }^{3} \mathrm{H}\right]$ lysergic acid diethylamide which had shown increased binding to serotonin receptors in selected nuclei of the brain stem in RS. In seven brain stem nuclei, mean binding was significantly higher in RS as compared to mature controls. These abnormalities of serotonin receptor binding, particularly in the nucleus of the solitary tract, the dorsal motor nucleus of the vagus and the nucleus centralis, may correlate with the abnormalities observed in the control of respiratory, cardiovascular and gastrointestinal function in RS.

Substance $P$ is an 11-amino acid neuropeptide with hypotensive and spasmogenic properties which was first discovered in intestinal extracts in 1931. Such peptides are found in the neurons of the central, peripheral and enteric nervous systems. While Substance Pis concentrated in the intestinal wall and is a stimulator of gastro-intestinal smooth muscle contraction, it is also abundant in dorsal root ganglia of the spinal cord and is widely distributed through the central nervous system, including the hypothalamus, corpus striatum (excitatory neurons) and substantia nigra. The striatonigral tract appears to contain the majority of the Substance Pfibres that give rise to the dense plexus in the substantia nigra, and it seems likely ${ }^{103,104}$ that Substance Pacts as a neurokinin there, possibly with direct effect upon dopaminergic neurons. It may also play a role in emotional disorders. ${ }^{105}$ The distribution of $\left[{ }^{3} \mathrm{H}\right]$-Substance $\mathrm{P}$ receptors suggests that Substance Pis probably also involved in the control of sensory processes such as pain, vision, hearing and olfaction. ${ }^{106}$

An elevated level of Substance Pin CSF has been reported in psychiatric patients ${ }^{107}$ and in the fibromyalgia syndrome, ${ }^{108}$ whereas a reduced level has been found in congenital sensory neuropathy with anhidrosis, in peripheral neuropathy with autonomic dysfunction and in Machado-Joseph disease.

In 1997, Matsuishi et al ${ }^{109}$ studied the CSF level of Substance $\mathrm{P}$ in 20 cases of RS (16 girls, four women) and in 28 control subjects by radioimmunoassay. The level in Rett patients was very significantly lower than in childhood controls $(\mathrm{P}<0.001)$ and also significantly lower $(\mathrm{P}=0.03)$ than in adult controls. In the Rett girls the level was also significantly lower than in children with nonspecific mental retardation $(\mathrm{P}=0.04)$. The levels in epilepsy and in Guillain-Barré syndrome were normal, while the means in 14 cases of Parkinson's disease and nine cases of multiple system atrophy were only slightly below average. The authors wondered whether Substance $\mathrm{P}$ was associated with dopaminergic neurons and whether the low CSF level in RS might be related to the neurological impairment.

Recently, Deguchi et al $^{110}$ studied the anatomic localization and intensity of Substance Pimmunoreactivity in the brains of 14 patients with RS, as compared with the brains of ten agematched normal patients. Substance P immunoreactivity was significantly decreased in RS tissue in the following regions: dorsal horns, intermediolateral column of the spinal cord, spinal trigeminal tract, solitary tract and nucleus, parvocellular and pontine radicular nuclei, and locus ceruleus. A less significant decrease of Substance P immunoreactivity was found in the substantia nigra, central grey matter of the midbrain, frontal cortex, caudate, putamen, globus pallidus and thalamus. Antiglial fibrillary acidic protein-positive astrocytes were increased in the areas in which Substance P immunoreactivity was decreased but significant gliosis also occurred in other regions. The authors wondered whether reduced Substance Pwas contributing to the autonomic dysfunction in $\mathrm{RS}$.

\section{OTHER METABOLIC FEATURES}

With respect to other metabolic characteristics, it has long been known that serum and spinal fluid levels of lactate and pyruvate may be slightly raised. Matsuishi et $\mathrm{al}^{111}$ analyzed lactate, pyruvate and citric acid cycle intermediates in the spinal fluid of Rett patients by liquid chromatography. The lactate, pyruvate, alpha-ketoglutarate and malate were significantly elevated in the Rett girls compared to controls. On the other hand, spinal fluid citrate, cis-aconitate, succinate, fumarate and oxaloacetate were not significantly different. Lactate elevation correlated significantly with apnoea, and lactate and pyruvate levels were influenced by hyperventilation; thus the changes may be considered as secondary to abnormal respirations. Further extensive studies of oxidative metabolism by Haas and colleagues $^{112}$ in 1995 were essentially negative, without evidence for any abnormal enzymes affecting pyruvate, citrate or biotin, and with normal findings in muscle mitochondria (including DNAstudies).

Spinal fluid endorphin levels in RS were found to be raised; ${ }^{113-116}$ the reason for this is not clear. Plasma levels were normal. The amounts of endorphin in different parts of the brain appear to vary and lowering of spinal fluid levels by treatment with naltrexone ${ }^{117}$ did not improve mental development in Rett girls.

Investigation of membrane cerebral lipids by Lekman et al ${ }^{118}$ in 1991 showed abnormality of gangliosides with reduced proportions of GD1a and GT1b in RS patients, possibly connected with abnormal development of synaptic connections. These lipids were also recently shown to be low in the spinal fluid of Rett girls ${ }^{119}$ in comparison to age-matched healthy controls. In 11 patients with infantile neuronal ceroid lipofuscinosis not only GD1a and GT1b but also GN1 and GD1b were significantly reduced in the spinal fluid. 


\section{AMINOACIDS}

In addition to the derivatives of dopamine, serotonin and catecholamines there has been much interest in glutamic and $\mathrm{N}$ methyl-D aspartic acid and their receptors. The spinal fluid levels of glutamate in RS had been considered normal until 1992, when Hamberger et al ${ }^{120}$ found them to be raised. This was confirmed by Lappalainen and Riikonen ${ }^{121}$ who noted that the mean level of glutamate in the CSF from 11 girls with RS was significantly higher than in controls. Since glutamate is the major excitatory neurotransmitter in the central nervous system and may contribute to seizures and neuronal damage, Uldall and colleagues ${ }^{122}$ suggested the use of lamotrigine in Rett girls with epilepsy, as the anticonvulsant effect of this medication is probably largely due to inhibition of glutamate release. Stenbom et $\mathrm{al}^{123}$ performed a pilot study of the use of lamotrigine in 12 Rett girls and found it moderately successful with respect to both seizures and behaviour. Giordano et al ${ }^{124}$ had similarly encouraging results in five patients with RS. Alterations in the function of glutamate receptors also have to be considered as they affect activity-dependent modulation of synaptic numbers in the developing brain. ${ }^{125} \mathrm{With}$ respect to these glutamate receptors recent studies ${ }^{126}$ have shown that autoradiographic labelling in the superior frontal gyrus of nine autopsied Rett brains demonstrated a trend for N-methyl-Daspartate (NMDA), $\alpha$-amino-3-hydroxy-5-methyl-4-isoxazole propionic acid (AMPA) and metabotropic receptors to have a higher density in infants and young girls before the age of ten years than in controls. After the first decade, the densities fall below those of controls and this might be correlated with a change to reduced psychomotor regression and seizures in the older girls. The reader may be reminded that similar significant inverse correlations with age have been observed for free 3methoxy-4-hydroxyphenylglycol (MHPG), 5-hydroxyindoleacetic acid and homovanillic acid (HVA) concentrations in the spinal fluid of neurologically normal children. ${ }^{127}$ However, in 1999, Blue and her colleagues ${ }^{128}$ further investigated the levels of NMDA, AMPA, kainate (KA) and metabotropic glutamate receptors and GABA receptors in the caudate, putamen and globus pallidus of postmortem brain slices from nine Rett girls and ten age-related controls. Significant reductions in AMPA and NMDAreceptor density in the putamen and in KA receptor density in the caudate were found in Rett patients aged ten years or more, compared to controls. In contrast, metabotropic glutamate receptor density in basal ganglia of Rett patients was not altered significantly, though it showed more reduction with age than in controls. GABA receptor density was strikingly increased in the caudate of young RS patients but declined by $23 \%$ in the older ages vs. an increase of $14 \%$ in controls and little change in putamen.

With respect to amino acid metabolism, Satoi et al ${ }^{129}$ recently reported decreased CSF levels of $\beta$-phenylethylamine (PEA) in RS. This is an endogenous amine synthesized by decarboxylation of phenylalanine in dopaminergic neurons of the nigrostriatal system. Satoi and his colleagues measured CSF PEAlevels in 17 children with RS, in 13 control children with no neurologic disease, and in patients with other neurological diseases including four with epilepsy and mental retardation and five with autistic disorder. The $17 \mathrm{RS}$ patients included nine in
Stage II, seven in Stage III and one in Stage IV. The authors also measured the CSF levels of HVA and MHPG. The mean CSF level of PEA in patients with RS was significantly lower than that of controls, being $31 \%$ of control values ( $p<0.05$ ). The CSF PEA levels in Stage II were significantly lower than those in Stage III ( $p<0.05)$. The mean CSF levels of PEA in children with epilepsy and mental retardation, or autistic disorder were not significantly different from controls. The mean CSF levels of HVA and MHPG in patients with RS were also not significantly different from those in controls. The authors wondered whether the lower spinal fluid PEA levels in RS might be due to dopamine system impairment, and they then found that the PEA level in CSF was also low in Parkinson's disease.

\section{NeURoIMAging}

Routine x-ray films in RS demonstrate only somewhat small head size. Serial computerized tomograms may show slowly progressive cortical atrophy after the age of two years, particularly in frontal and occasionally in temporal areas. Magnetic resonance imaging (MRI) shows normal myelination. Casanova et al ${ }^{130}$ used quantitative MRI imaging in RS and found generalized atrophy of both cerebral hemispheres but a disproportionately larger reduction in the volume of the caudate nuclei. On sagittal imaging the size and shape of posterior fossa structures did not appear significantly different from those of control subjects. Murakami et $\mathrm{al}^{131}$ examined age-related changes from single midsagittal and coronal slices. They reported a global hypoplasia in patients with RS and suspected a progressive age-related atrophy of the cerebellum. Reiss et al ${ }^{132}$ performed volumetric studies in 11 Rett subjects and 15 normal control girls. They confirmed the global reduction in brain volume and a disproportionate volume reduction in the caudate nucleus. They also noted a significant increase in the volume of total and extraventricular CSF in Rett girls. They observed greater reduction in the volume of grey than white matter, with frontal regions showing the largest diminution.

Subramaniam et al ${ }^{133}$ performed detailed volumetric MRI studies in 20 girls with RS and compared them with individually age- and gender-matched normal controls. The RS patients showed global reduction in grey and white matter volumes. The prefrontal, posterior frontal and anterior temporal regions showed the largest bilateral decreases in grey matter volume, whereas white matter volume was reduced uniformly throughout the brain. Of subcortical nuclei, the caudate showed the largest, and the thalamus the smallest reduction. Of posterior fossa structures, midbrain and cerebellum showed significant volume reductions in the Rett group. The size of the pons was statistically indistinguishable from that of controls. Within the cerebellar vermis, the anterior region (lobules I-V) showed a larger reduction than the posterior region (lobules VI-X). Overall brain size was not correlated with age in either group.

In our own studies, visual inspection of MRI scans in nine Rett girls, aged 16 to 26 years, showed four with cerebral tissue loss, which was frontal-temporal in distribution in three. Two subjects had mild cerebellar tissue loss. Volumetric findings of these MRI scans were compared with those of selected young volunteers of the same age and showed significantly smaller caudate heads and thalami in the girls with RS, whereas there 
was no significant difference between the volumes of lentiform nuclei in the nine girls with RS and their controls.

Cerebral proton magnetic resonance spectroscopy has also been used in Rett girls. No suggestion of mitochondrial disorder was found. ${ }^{134} \mathrm{~N}$-acetyl aspartate (NAA) was reported ${ }^{135,136}$ to be decreased in grey matter of older patients, particularly in frontal lobes, cerebellum and basal ganglia, in keeping with neuronal and/or axonal loss in these regions. Using ${ }^{1} \mathrm{H}$ spectroscopic imaging at 4.1 Tesla, Pan et al ${ }^{137}$ evaluated glutamate, creatine (Cr) and $\mathrm{N}$-acetyl aspartate in six girls with RS and four normal sibling controls. In the Rett girls, the level of NAAwas found to be reduced in white matter in relation to $\mathrm{Cr}$, while the glutamate to NAA ratio was elevated in grey matter.

Horská et al ${ }^{138}$ similarly performed quantitative ${ }^{1} \mathrm{H}$ magnetic resonance spectroscopic imaging in 17 girls with RS, mean age six years four months \pm two years nine months, and nine healthy control girls, mean age nine years nine months \pm four years six months. In RS patients the average choline (Cho) concentration was $12 \%$ higher $(\mathrm{p}<0.005)$ and average NAA concentration $11 \%$ lower ( $\mathrm{p}<0.0001$ ) compared with the control group. Regional metabolic differences included significantly lower NAA concentration in the frontal grey and white matter, insula, and hippocampus in RS; no differences in regional Cho and $\mathrm{Cr}$ concentrations were found. Patients with seizures had higher average concentrations of $\mathrm{Cho}, \mathrm{Cr}$, and NAA compared with those without seizures. It was presumed that the loss of NAA reflected reduced neuronal and dendritic size, while the increased choline concentration might result from gliosis.

Single photon emission computed tomography (SPECT) and the measurement of cerebral blood flow $(C B F)$. Nielsen et al ${ }^{139}$ applied SPECT in seven patients with RS and noted that CBF was reduced to $88 \%$ of that in age-matched control subjects. Specific reduction was noted in the prefrontal and temporoparietal regions, with sparing of primary sensorimotor cortex. This was an immature pattern reminiscent of infants. Lappalainen et al ${ }^{140}$ studied $99^{\mathrm{m}}$ Tc-HMPAO SPECT in 13 Rett patients with a mean age of 8.4 years and found hypoperfusion in 11 , particularly in bifrontal areas, but also in other cortical parts except the occipital lobes. There appeared to be an association between early onset of RS and severity of hypoperfusion. Bjure et al ${ }^{141}$ also studied regional CBF in RS. Sixteen Rett girls and one 24-year-old Rett woman were compared with 16 neurologically healthy children. Hypoperfusion of the frontal lobes and parts of the midbrain was found in the Rett cases, with significant differences to controls at the latest by the age of three to four years. It was concluded that abnormalities in these areas were compatible with the view that structures in the midbrain and in frontal lobes may have particular pathophysiological relevance in RS.

A further study of CBF in RS was performed by Burroni et $\mathrm{al}^{142}$ who tested perfusion abnormalities with $99^{\mathrm{m}}$ Tc-ethylcysteinate-dimer (ECD). Blood flow in 12 girls with RS was compared with that in an age-matched reference group. This revealed a considerable global reduction in cerebral perfusion in the Rett girls, particularly in Stage IV. It was demonstrated that the $99^{\mathrm{m}}$ Tc-ECD measurement was sensitive in detecting hypoperfused areas in Rett girls even prior to the appearance of atrophy on magnetic resonance imaging.

Positron Emission Tomography (PET). Injected isotopes have also been used with PET in the study of RS. Thus Yoshikawa et $\mathrm{al}^{143}$ investigated oxygen metabolism in six RS patients of different ages. The authors noted the loss of the developmental increase of frontal vs. temporal blood flow ratio in RS after two years of age. Low oxygen extraction also suggested abnormal CNS energy metabolism. In 1986, PET with $\left[{ }^{11} \mathrm{C}\right]-\mathrm{N}-$ methylspiperone was reported by Harris, Wong and others ${ }^{144}$ in a Rett patient aged 25 years. $\mathrm{D}_{2}$ dopamine receptor activity was found to be at the lower range of normal for the age, while spinal fluid neurotransmitter levels were normal, including homovanillic acid, the final metabolite of dopamine.

$\left[{ }^{18} \mathrm{~F}\right]-6$-fluoro-L-dopa (FD) has been used widely for studies of the presynaptic nigrostriatal dopaminergic pathway. The metabolism of FD closely matches that of levodopa. Striatal FD uptake correlates highly with the number of pigmented nigral cells in humans at autopsy. ${ }^{145}$ Also, in monkeys it has been shown that striatal FD uptake constants had highly significant correlations with both number and size of dopaminergic neurons and significant correlations with striatal levels of dopamine and total catecholamines, demonstrating that PET-FD measurements provided a good index of the integrity of the nigrostriatal pathway. ${ }^{146}$ Three-dimensional image registration may also be used with PET. ${ }^{147,148}$ Dopamine receptor binding can also be studied. Various radioligands have been used which bind to receptors, e.g. $\left[{ }^{11} \mathrm{C}\right]$ raclopride or $\left[{ }^{11} \mathrm{C}\right] \mathrm{N}$-methylspiperone for $\mathrm{D}_{2}$ receptors.

In 1998, Wong et al ${ }^{149}$ investigated dopamine transporter (DAT) protein which is reported to have very high affinity and substrate specificity. Reuptake of dopamine (DA) into the presynaptic neuron by means of DAT is believed to be the primary mechanism for termination of dopaminergic neuro-transmission. The highest concentrations of DATs are found in the basal ganglia, corresponding to the amount of DA nerve terminals in this brain region. The authors studied 12 patients with RS following a single injection of $\left[{ }^{11} \mathrm{C}\right]$ WIN35428, a marker of the DAT. On comparison with matched controls they noted a significant reduction in binding potential $\left(\mathrm{k}_{3} / \mathrm{k}_{4}\right)$ of up to $45 \%$ both in the caudate and in the putamen of the patients. While they found low to low-normal values for receptor density (Bmax) of postsynaptic $\mathrm{D}_{2}$-like dopamine receptors in the caudate in the 12 Rett girls measured with $\left[{ }^{11} \mathrm{C}\right] \mathrm{N}$-methylspiperone, they recognized that, on the contrary, Chiron et $\mathrm{al}^{150}$ had reported markedly increased specific binding of $\left[{ }^{123} \mathrm{I}\right]$ iodolisuride, a SPECT tracer for the $\mathrm{D}_{2}$-like dopamine receptor, in 11 children with RS. Those authors had concluded that dopaminergic deficiency in RS leads to up-regulation of post-synaptic receptors. However, as noted by Blue et al, ${ }^{126}$ age-related changes in receptor density have to be correlated with reduction in older Rett girls. Naidu et al ${ }^{151}$ now report that they studied 12 adult patients (15-39 years) with $\left[{ }^{11} \mathrm{C}\right]-\mathrm{N}$-methylspiperone who showed low-normal levels of $\mathrm{D}_{2}$ dopamine receptors, whereas Chiron et $\mathrm{al}^{150}$ had investigated children of only $4-15$ years. The question then arises whether the difference in the finding can be explained by the normal age-dependent decline of nigrostriatal dopaminergic function with age on PETstudies. ${ }^{152}$ Naidu and her colleagues $^{151}$ suggest age-specific changes in RS where the increase in receptors in younger patients with subsequent reductions in the older ones parallels the clinical worsening in Stage II of the disease followed by amelioration of symptoms. 
Evidently 16 patients, aged 18-40 years, were utilized to study DATs in caudate and putamen by WIN-35428, and these were found to be in the low-normal range in the older patients compared to controls.

In our own experience with PET (to be published), nine girls with RS, aged 14 to 26 years, showed a reduced mean uptake of intravenous 6-fluoro- $\left[{ }^{18} \mathrm{~F}\right]$-L-dopa by about $13.1 \%$ in the caudate and $12.4 \%$ in the putamen, as compared to female controls. On the other hand, the binding of intravenous $\left[{ }^{11} \mathrm{C}\right]$ raclopride showed an increase of about $9.7 \%$ in caudate and $9.6 \%$ in putamen, as compared to controls. These differences are statistically significant and suggest reduced striatal dopaminergic activity with compensatory increase in $\mathrm{D}_{2}$ receptor activity.

\section{DISCUSSION}

As pointed out by Budden ${ }^{158}$ and $\mathrm{Naidu}^{86}$ the remarkable feature setting the RS apart from most other neurodegenerative diseases is that it shows rapid clinical deterioration during active brain growth, after which there is relative stability for decades. Some pathological and clinical features suggest an onset during prenatal development and we now know that, in $75-80 \%$ of classical cases, there is a mutation in the gene $M E C P 2$ encoding the X-linked methyl-CpG binding protein 2 which combines methylated DNA and links it with transcriptional repression mediated by histone deacetylases. However, the exact mechanism by which neurons, dendrites and axons in the brain are liable to get damaged during synaptogenesis remains obscure.

Nomura ${ }^{153}$ continues to report from her polysomnographies that the sleep-wake rhythm in RS shows irregularities in the time of waking up and falling asleep at night and also profound daytime sleep compared with normal children of the same age. These abnormalities indicate dysfunction of dorsal raphe serotonergic (5HT) neurons and noradrenergic brain stem neurons. The parameters of REM sleep are preserved normally, while there are particular abnormalities in NREM sleep, i.e. phasic inhibition is affected preserving tonic inhibition. These results suggested that the brain of RS seems to develop normally until 36 weeks of gestation but becomes abnormal in the period from 38 gestational weeks to the three to four postnatal months. As for the cortical involvement, the sensory evoked potentials have suggested delayed intracortical conduction and early aging, whereas transcranial magnetic stimulation revealed shorter central motor conduction time and impairment of cortico-spinal tracts in the advanced stage.

In the differential diagnosis of RS, the first thought is of infantile autism, which may also show a significant deterioration in the second year. In a recent authoritative statement on the screening and diagnosis of autism, Filipek et al ${ }^{154}$ emphasize the qualitative impairment of social interaction and also the impairment of communication (particularly language) and restrictive repetitive and stereotypic behaviour (as distinct from symbolic or imaginative play). Many of these impaired cognitive functions have been traditionally attributed to the left hemisphere. On the other hand, autistic children may show relatively proficient visual-spatial functions and perceptions of musical stimuli, processes attributed to the right hemisphere. In these respects autistic children resemble those with RS, and both are unusually liable to be left-handed.$^{55}$ Chiron et al ${ }^{155}$ used ${ }^{133} \mathrm{Xe}$-SPECT to measure left/right asymmetry and absolute values of regional $\mathrm{CBF}$ in 18 autistic children aged four to 17 years and ten age-matched controls. All controls, but only ten children with autism, were right-handed. Left-to-right indices, both hemispheric and regional, were positive in controls, indicating higher left than right $\mathrm{CBF}$ values, but were negative in patients with autism.

Autistic children may have mild ataxia but less than Rett girls after the first year. They seldom hyperventilate when relaxed. Also, among autistic children boys outnumber girls at least 3:1, and in the girls the new genetic testing for MECP2 should now be helpful in the distinction from RS. Further, it has long been suspected that children with autism may have increased blood levels of serotonin and several observers have reported that administration of serotonin reuptake inhibitors may improve compulsive symptoms, repetitive movements and social function in autistic adults. The development of $\alpha\left[{ }^{11} \mathrm{C}\right]$ methyl-Ltryptophan as a tracer for PET now allows a direct in vivo measurement of serotonin synthesis in humans. Chugani et al ${ }^{156}$ recently reported that with this method they had obtained global brain values for serotonin synthesis capacity for 30 autistic children, eight nonautistic siblings and 16 epileptic children without autism. For nonautistic children, serotonin synthesis capacity was more than $200 \%$ of adult values until the age of five years and then declined towards adult values, earlier in girls than in boys. In autistic children it increased gradually between the ages of two and 15 years to values 1.5 times adult normal values and showed no sex difference. These data suggest that humans undergo a period of high brain serotonin synthesis capacity during childhood and that this developmental process is disrupted in autism. It would be interesting to have a similar investigation in RS.

Another condition to be mentioned in the differential diagnosis of RS is the Angelman (or Happy Puppet) syndrome. These retarded children also have a normal perinatal history and head circumference, with subsequent developmental delay and may also develop seizures. However, both sexes are involved equally, and the infants have a fairly characteristic phenotype with a tendency to macrostomia and prognathism, flat occiput and posterior occipital groove as well as a happy disposition and inappropriate laughter, without gross breathing irregularities and without developmental regression in the second year. ${ }^{157}$ They also have a characteristic abnormality of chromosome 15q11-13 like that in the Prader-Willi syndrome but with paternal uniparental disomy. The $M E C P 2$ gene defect is not seen.

A child neurologist may wish to look further to exclude congenital metabolic defects and possible brain injury from anoxia, ischemia or trauma. Neuroimaging may be required in academic investigation.

The clinical management of RS is beyond the scope of this paper. It has been described in detail by Budden. ${ }^{158,159}$ The value of a multidisciplinary team and of the parent organizations and their conferences and research support is recognized.

\section{ACKNOWLEDGMents}

The authors thank Dr. Sarojini Budden, Dr. Jon Stoessl, Dr. Doris Doudet and Dr. Helena H. Ho. 


\section{REFERENCES}

1. Rett, A. Über ein eigenartiges hirnatrophisches Syndrom bei Hyperammonämie im Kindesalter. Wien Klin Wochenschr 1966; 116: 723-726.

2. Ishikawa A, Goto T, Narasaki M, et al. A new syndrome (?) of progressive psychomotor deterioration with peculiar stereotype movement and autistic tendency: a report of three cases. Brain Dev (Tokyo) 1978; Old Series No. 3:258 (Abstract in English).

3. Hagberg B, Aicardi J, Dias K, Ramos O. A progressive syndrome of autism, dementia, ataxia, and loss of purposeful hand use in girls: Rett's syndrome: report of 35 cases. Ann Neurol 1983; 14: 471-479.

4. Hagberg B, Witt-Engerström I. Rett syndrome: a suggested staging system for describing impairment profile with increasing age towards adolescence. Am J Med Genet 1986; 24: Suppl. 1: 47-59.

5. Rett Syndrome Diagnostic Criteria Work Group. Diagnostic criteria for Rett syndrome. Ann Neurol 1988; 23: 425-428.

6. Hagberg BA, Skjeldal $\mathrm{OH}$. Rett variants: a suggested model for inclusion criteria. Pediatr Neurol 1994; 11: 5-11.

7. Zappella M. The Rett girls with preserved speech. Brain Dev 1992; 14: 98-101.

8. Haas RH, Dixon SD, Sartoris DJ, Hennessy MJ. Osteopenia in Rett syndrome. J Pediatr 1997; 131: 771-774.

9. Leonard H, Thomson MR, Glasson EJ, et al. A population-based approach to the investigation of osteopenia in Rett syndrome. Dev Med Child Neurol 1999; 41: 323-328.

10. Leonard H, Thomson M, Glasson EJ, et al. Metacarpophalangeal pattern profile and bone age in Rett syndrome: further radiological clues to the diagnosis. Am J Med Genet 1999; 83: 88-95.

11. Motil KJ, Schultz RJ, Browning K, et al. Oropharyngeal dysfunction and gastroesophageal dysmotility are present in girls and women with Rett syndrome. J Pediatr Gastroenterol Nutr 1999; 29: 31-37.

12. Morton RE, Pinnington L, Ellis RE. Air swallowing in Rett syndrome. Dev Med Child Neurol 2000; 42: 271-275.

13. Hagberg B. Rett's syndrome: prevalence and impact on progressive severe mental retardation in girls. Acta Paediatr Scand 1985; 74: 405-408.

14. Kerr AM, Stephenson JBP. Rett's syndrome in the West of Scotland. Br Med J 1985; 291: 579-582.

15. Witt-Engerström I, Gillberg C. Rett syndrome in Sweden. J Autism Dev Disord 1987; 17: 149-150.

16. Akesson HO. Rett syndrome: the Swedish Genealogic Research Project. New data and present position. Eur Child Adolesc Psychiatry 1997; 6 (Suppl 1): 96-98.

17. Akesson HO, Hagberg B, Wahlstrom J. Rett syndrome, classical and atypical: genealogical support for common origin. J Med Genet 1996; 33: 764-766.

18. Pini G, Milan M, Zappella M. Rett syndrome in northern Tuscany: family tree studies. Clin Genet 1996; 50: 486-490.

19. Hollody K, Borvendeg K, Kosztolanyi G. Pedigree analysis of Hungarian Rett syndrome girls. Eur Child Adolesc Psychiatry 1997; 6 (Suppl 1): 99-100.

20. Leonard H, Bower C, English D. The prevalence and incidence of Rett syndrome in Australia. Eur Child Adolesc Psychiatry 1997; 6(Suppl 1): 8-10.

21. Skjeldal $\mathrm{OH}$, von Tetzchner S, Aspelung F, et al. Rett syndrome: geographic variation in prevalence in Norway. Brain Dev 1997; 19: $258-261$.

22. Witt-Engerström I, Forslund M. Mother and daughter with Rett syndrome. Dev Med Child Neurol 1992; 34: 1022-1023.

23. Leonard H, Silverstein J, Falk R, et al. Exploring the male phenotype. World Congress on Rett Syndrome 2000, Abstract PO-3, p 34

24. Vorsanova SG, Demidova IA, Ulas VY, et al. Cytogenetic and molecular-cytogenetic studies of Rett syndrome (RTT). A retrospective analysis of Russian cohort of RTT patients. World Congress on Rett Syndrome 2000, PO-31:48.

25. Schanen NC, Kurczynski TW, Brunelle D, et al. Neonatal encephalopathy in two boys in families with recurrent Rett syndrome. J Child Neurol 1998; 13: 229-231.

26. Wan M, Lee SSJ, Zhang X, et al. Rett syndrome and beyond: recurrent spontaneous and familial MECP2 mutations at CPG hotspots. Am J Hum Genet 1999; 65: 1520-1529.

27. Zoghbi HY, Percy AK, Schultz RJ, Fill JC. Patterns of $X$ chromosome inactivation in the Rett syndrome. Brain Dev 1990; 12: $131-135$

28. Ellison KA, Fill CP, Terwilliger $\mathrm{J}$, et al. Examination of $\mathrm{X}$ chromosome markers in Rett syndrome: exclusion mapping with a novel variation on multilocus linkage analysis. Am J Hum Genet 1992; 50: 278-287.

29. Schanen C, Francke U. A severely affected male born into a Rett syndrome kindred supports X-linked inheritance and allows extension of the exclusion map. Am J Hum Genet 1998; 63: 267269.

30. Sirianni N, Naidu S, Pereira J, et al. Rett syndrome: confirmation of X-linked dominant inheritance, and localization of the gene to Xq28. Am J Hum Genet 1998; 63: 1552-1558.

31. Xiang F, Zhang Z, Clarke A, et al. Chromosome mapping of Rett syndrome: a likely candidate region on the telomere of Xq. J Med Genet 1998; 35: 297-300.

32. Webb T, Clarke A, Hanefeld F, et al. Linkage analysis in Rett syndrome families suggests that there may be a critical region at Xq28. J Med Genet 1998; 35: 997-1003.

33. Schanen NC. Molecular approaches to the Rett syndrome gene. J Child Neurol 1999; 14: 806-814.

34. Amir RE, Van den Veyver IB, Wan M, et al. Rett syndrome is caused by mutations in X-linked $M E C P 2$, encoding methyl-CpGbinding protein 2. Nature Genet 1999; 23: 185-188.

35. Willard HF, Hendrich BD. Breaking the silence in Rett syndrome. Nature Genet 1999; 23: 127-128.

36. Hendrich BD. Methylation moves into medicine. Curr Biol 27 January 2000; 10: R60-R63.

37. Maraschio P, Zuffardi O, Dalla Fior T, Tiepolo L. Immunodeficiency, centromeric heterochromatin instability of chromosomes 1, 9 and 16, and facial anomalies: the ICF syndrome. J Med Genet 1988; 25: 173-180.

38. Amir RE, Van den Veyver IB, Schultz R, et al. Influence of mutation type and $\mathrm{X}$ chromosome inactivation on Rett syndrome phenotypes. Ann Neurol 2000; 47: 670-679.

39. Huppke P, Laccone F, Krämer N, Engel W, Hanefeld F. Rett syndrome: analysis of $\mathrm{MeCP} 2$ and clinical characterization of 31 patients. Hum Molec Genet 2000; 9: 1369-1375.

40. Van den Veyver IB, Zoghbi HY. Methyl-CpG binding protein 2 mutations in Rett syndrome. Curr Opin Genet Dev 2000; 10: 275279.

40a. Francke U. Spectrum of MECP2 mutations in Rett syndrome. World Congress on Rett Syndrome 2000; Symposium S-1;9

41. Cheadle JP, Gill H, Fleming N, et al. Long-read sequence analysis of the MECP2 gene in Rett syndrome patients: correlation of disease severity with mutation type and location. Hum Molec Genet 2000; 9: 1119-1129.

42. Nan X, Guy J, Hendrich B, et al. Biological function of the methylCPG binding protein $M E C P 2$. World Congress on Rett Syndrome 2000; Abstract KS-II:2.

43. Christodoulou J, Weaving L, Ellaway C, Leonard H, Bennetts B. $M E C P 2$ and Rett Syndrome (RS) - time for a mutation database? World Congress on Rett Syndrome 2000, PO-48:56.

44. Leonard $\mathrm{H}$, Bower $\mathrm{C}$. Is the girl with Rett syndrome normal at birth? Dev Med Child Neurol 1998; 40: 115-121.

45. Jellinger K, Armstrong D, Zoghbi HY, Percy AK. Neuropathology of Rett syndrome. Acta Neuropathol 1988; 76: 142-158.

46. Bauman ML, Kemper TL, Arin DM. Microscopic observations of the brain in Rett syndrome. Neuropediatrics 1995: 26: 105-108.

47. Oldfors A, Sourander P, Armstrong D, et al. Rett syndrome: cerebellar pathology. Pediatr Neurol 1990; 6: 310-314.

48. Armstrong DD. The neuropathology of Rett syndrome: overview 1994. Neuropediatrics $1995 ; 26$ : 100-104.

49. Haas RH, Love S. Peripheral nerve findings in Rett syndrome. J Child Neurol 1988: 3 (Suppl): 525-530.

50. Oldfors A, Hagberg B, Nordgren H, et al. Rett syndrome: spinal cord neuropathy. Pediatr Neurol 1988; 4: 172-174. 
51. Jellinger K, Grisold W, Armstrong D, et al. Peripheral nerve involvement in the Rett syndrome. Brain Dev 1990; 12: 109-114.

52. Kitt CA, Wilcox BJ. Preliminary evidence for neurodegenerative changes in the substantia nigra of Rett syndrome. Neuropediatrics 1995; 26: 114-118.

53. Belichenko PV, Hagberg B, Dahlström A. Morphological study of neocortical areas in Rett syndrome. Acta Neuropathol 1997; 93: $50-61$.

54. Nomura Y, Segawa M. Clinical features of the early stage of the Rett syndrome. Brain Dev 1990; 12: 16-19.

55. Witt-Engerström I. Age related occurrence of signs and symptoms in the Rett syndrome. Brain Dev 1992; 14: S11-S20.

56. Naidu S, Hyman S, Harris EL, et al. Rett syndrome studies of natural history and search for a genetic marker. Neuropediatrics 1995; 26: 63-66.

57. Glaze DG, Frost JD, Zoghbi HY, et al. Rett's syndrome: correlation of electroencephalographic characteristics with clinical staging. Arch Neurol 1987; 44: 1053-1056.

58. Robertson R, Langill L, Wong PKH, Ho HH. Rett syndrome: EEG presentation. Electroencephalogr Clin Neurophysiol 1988; 70: 388-395.

59. Ho HH, Wong PK, Robertson R. Rett syndrome: clinical profile and EEG abnormalities. Clin Invest Med 1988; 11: 234-241.

60. Niedermeyer E, Naidu S. Further EEG observations in children with the Rett syndrome. Brain Dev 1990; 12: 53-54.

61. Elian M, Rudolf ND. EEG and respiration in Rett syndrome. Acta Neurol Scand 1991; 83: 123-128.

62. Niedermeyer E, Naidu SB, Plate C. Unusual EEG theta rhythms over central region in Rett syndrome: considerations of the underlying dysfunction. Clin Electroencephalogr 1997; 28: 36-43.

63. Glaze DG, Schultz RJ, Frost JD. Rett syndrome: characterization of seizures versus nonseizures. Electroencephalogr Clin Neurophysiol 1998; 106: 79-83.

64. Guerrini R, Bonanni P, Parmeggiani L, et al. Cortical reflex myoclonus in Rett syndrome. Ann Neurol 1998; 43: 472-479.

65. Yamanouchi H, Kaga M, Arima M. Abnormal cortical excitability in Rett syndrome. Pediatr Neurol 1993; 9: 202-206.

66. Heinen F, Petersen H, Fietzek U, et al. Transcranial magnetic stimulation in patients with Rett syndrome: preliminary results. Europ Child Adolesc Psychiatry 1997; 6(Suppl 1): 61-63.

67. Nezu A, Kimura S, Takeshita S, Tanaka M. Characteristic response to transcranial magnetic stimulation in Rett syndrome. Electroencephalogr Clin Neurophysiol 1998; 109: 100-103.

68. Badr GG, Witt-Engerström I, Hagberg B. Brain stem and spinal cord impairment in Rett syndrome: Somatosensory and auditory evoked responses investigations. Brain Dev 1987; 9: 517-522.

69. Bader GG, Witt-Engerström I, Hagberg B. Neurophysiological findings in the Rett syndrome, I:EMG, conduction velocity, EEG and somatosensory-evoked potential studies. Brain Dev 1989; 11: 102-109.

70. Nomura Y, Segawa M, Hasegawa M. Rett syndrome - clinical studies and pathophysiological considerations. Brain Dev 1984: $6 ; 475-486$

71. Nomura Y, Segawa M, Higurashi M. Rett syndrome - an early catecholamine and indolamine deficient disorder? Brain Dev 1985; 7: 334-341.

72. Nomura Y, Segawa M. Anatomy of Rett syndrome. Am J Med Genet 1986; 24: 289-303.

73. Segawa M, Nomura Y. Pathophysiology of the Rett syndrome from the standpoint of polysomnography. Brain Dev 1990; 12: 55-60.

74. Segawa M, Nomura Y. Polysomnography in the Rett syndrome. Brain Dev 1992; 14 (Suppl) S46-S54.

75. Felten DL, Hallman H, Jonsson G. Evidence for a neurotrophic role of noradrenaline neurons in the postnatal development of rat cerebral cortex. J Neurocytol 1982; 11: 119-135.

76. Perry TL, Dunn HG, Ho HH, Crichton JU. Cerebrospinal fluid values for monoamine metabolites, gamma aminobutyric acid, and other amino compounds in Rett syndrome. J Pediatr 1988; 112: $234-238$.

77. Lekman A, Witt-Engerström I, Holmberg B, et al. CSF and urine biogenic amine metabolites in Rett syndrome. Clin Genet 1990; 37: $173-178$
78. Lekman A, Witt-Engerström I, Gottfries J, et al. Rett syndrome: biogenic amines and metabolites in postmortem brain. Pediatr Neurol 1989; 5: 357-362.

79. Wenk GL, Naidu S, Moser H. Altered neurochemical markers in Rett syndrome. Ann Neurol 1989; 26: 467.

80. Wenk GL, Naidu S, Casanova MF, et al. Altered neurochemical markers in Rett's syndrome. Neurology 1991; 41: 1753-1756.

81. Johnston MV, Hohmann C, Blue M. Neurobiology of Rett syndrome. Neuropediatrics 1995; 26: 119-122.

82. Berger-Sweeney J. The effects of neonatal basal forebrain lesions on cognition: towards understanding the developmental role of the cholinergic basal forebrain. Internat J Dev Neurosci 1998; 16: 603-612.

83. Wenk GL. Alterations in dopaminergic function in Rett syndrome. Neuropediatrics 1995; 26: 123-125.

84. Wenk GL. Rett syndrome: evidence for normal dopaminergic function. ibid. 1996; 27: 256-259.

85. Kaufmann WE, Taylor CV, Hohmann CF, et al. Abnormalities in neuronal maturation in Rett syndrome neocortex: preliminary molecular correlates. Eur Child Adolesc Psychiatry 1997; 6(Suppl 1): 75-77.

86. Naidu S. Rett syndrome: a disorder affecting early brain growth. Ann Neurol 1997; 42: 3-10.

87. Li Y, Holtzman DM, Kromer LF, et al. Regulation of TrkA and ChAT expression in developing rat basal forebrain: evidence that both exogenous and endogenous NGF regulate differentiation of cholinergic neurons. J Neurosci 1995; 15: 2888-2905.

88. Lin LF, Doherty DH, Lile JD, et al. GDNF: a glial cell line derived neurotrophic factor for midbrain dopaminergic neurons. Science 1993; 260: 1130-1132.

89. Lappalainen R, Lindholm D, Riikonen R. Low levels of nerve growth factor in cerebrospinal fluid of children with Rett syndrome. J Child Neurol 1996; 11: 296-300.

90. Vanhala R, Korkonen L, Mikelsaar M, et al. Neurotrophic factors in cerebrospinal fluid and serum of patients with Rett syndrome. J Child Neurol 1998; 13: 429-433.

91. Riikonen R, Vanhala R. Levels of cerebrospinal fluid nerve-growth factor differ in infantile autism and Rett syndrome. Dev Med Child Neurol 1999; 41: 148-152.

92. Wenk GL, Hauss-Wegrzynriak B. Altered cholinergic function in the basal forebrain of girls with Rett syndrome. Neuropediatrics 1999; 30: 125-129.

93. Hohmann CF, Berger-Sweeney J. Cholinergic regulation of cortical development and plasticity. New twists to an old story. Perspect Dev Neurobiol 1998; 5: 401-425.

94. Nomura Y, Kimura K, Arai H, Segawa M. Involvement of the autonomic nervous system in the pathophysiology of Rett syndrome. Eur Child Adolesc Psychiatry 1997; 6(Suppl 1): 4246.

95. Julu PO, Kerr AM, Hansen S, et al. Functional evidence of brain stem immaturity in Rett syndrome. Eur Child Adolesc Psychiatry 1997; 6(Suppl 1): 47-54.

96. Sekul EA, Moak JP, Schultz RJ, et al. Electrocardiographic findings in Rett syndrome: explanation for sudden death? J Pediatr 1994; 125: 80-82.

97. Dearlove OR, Walker RWM: Case Reports: Anaesthesia for Rett Syndrome. Paediatr Anaesth 1996; 6: 155-158.

98. Ellaway CJ, Sholler G, Leonard H, Christodoulou J. Prolonged QT interval in Rett syndrome. Arch Dis Child 1999; 80: 470-472.

99. Guideri F, Acampa M, Hayek G, et al. Reduced heart rate variability in patients affected with Rett syndrome. A possible explanation for sudden death. Neuropediatrics 1999; 30: 146148.

100. Witt-Engerström I, Kerr A, eds. Workshop on autonomic function in Rett syndrome. Swedish Rett Center, Frösön, Sweden, May 1998. Brain Dev 1998; 20: 323-326.

101. Ljungberg A-W, Hagberg B. Rett syndrome, one-sided sympathectomy. Unilateral foot normalization. Eur Child Adolesc Psychiatry 1997; 6(Suppl 1): 55.

102. Armstrong DD, Panigrahy A, Sleeper LA, Kinney HC. Preliminary studies demonstrating increased $\left[{ }^{3} \mathrm{H}\right]$ lysergic acid diethylamide $\left(\left[{ }^{3} \mathrm{H}\right] \mathrm{LSD}\right)$ binding to serotonin receptors in selected nuclei of 
the brain stem in Rett syndrome. See reference 100

103. Jessell TM, Emson PC, Paxinos G, Cuello AC. Topographic projections of Substance P and GABA pathways in the striatoand pallido-nigral system: a biochemical and immunohistochemical study. Brain Res 1978; 152: 487-498.

104. Nikolaus S, Huston JP, Hasenohrl RU. Reinforcing effects of neurokinin Substance Pin the ventral pallidum: mediation by the tachykinin NKI receptor. Eur J Pharmacol 1999; 370: 93-99.

105. Kramer MS, Cutler N, Feighner J, et al. Distinct mechanism for antidepressant activity by blockade of central Substance P receptors. Science 1998; 281: 1640-1645.

106. Nicoll RA, Schenker C, Leeman SE. Substance P as a transmitter candidate. Ann Rev Neurosci 1980; 3: 227-268.

107. Rimon R, Greves PL, Nyberg F, et al. Elevation of Substance P-like peptides in the CSF of psychiatric patients. Biol Psychiatry 1984; 19: 509-516.

108. Russell IJ, Orr MD, Littman B, et al. Elevated cerebrospinal fluid levels of Substance Pin patients with the fibromyalgia syndrome. Arthritis Rheum 1994; 37: 1593-1601.

109. Matsuishi T, Nagamitsu S, Yamashita Y, et al. Decreased cerebrospinal fluid levels of Substance $\mathrm{P}$ in patients with Rett syndrome. Ann Neurol 1997; 42: 978-981.

110. Deguchi K, Antalffy BA, Twohill LJ, et al. Substance P immunoreactivity in Rett syndrome. Pediatr Neurol 2000; 22: 259-266.

111. Matsuishi T, Urabe F, Percy AK, et al. Abnormal carbohydrate metabolism in cerebrospinal fluid in Rett syndrome. J Child Neurol 1994; 9: 26-30.

112. Haas RH, Nasirian F, Hua X, et al. Oxidative metabolism in Rett syndrome: 2. Biochemical and molecular studies. Neuropediatrics 1995; 26: 95-99.

113. Budden SS, Myer EC, Butler IJ. Cerebrospinal fluid studies in the Rett syndrome: biogenic amines and beta endorphins. Brain Dev 1990; 12: 81-84.

114. Echenne B, Bressot N, Bassir M, et al. Cerebrospinal fluid Bendorphin and cortisol study in Rett syndrome. J Child Neurol 1991; 6: 257-262.

115. Nielsen JB, Bach FW, Buchholt J, Lou H. Cerebrospinal fluid Bendorphin in Rett syndrome. Dev Med Child Neurol 1991; 33: 406-411.

116. Myer EC, Tripathi HL, Brase DA, Dewey WL. Elevated CSF Bendorphin immunoreactivity in Rett's syndrome: report of 158 cases and comparison with leukemic children. Neurology 1992; 42: 357-360

117. Percy AK, Glaze DG, Schultz RJ, et al. Rett syndrome: controlled study of an oral opiate antagonist, naltrexone. Ann Neurol 1994; 35: 464-470.

118. Lekman AY, Hagberg BA, Svennerholm LT. Membrane cerebral lipids in Rett syndrome. Pediatr Neurol 1991; 7: 186-190.

119. Lekman AY, Hagberg BA, Svennerholm LT. Cerebrospinal fluid gangliosides in patients with Rett syndrome and infantile neuronal ceroid lipofuscinosis. Eur J Paediatr Neurol 1999; 3: 119-123.

120. Hamberger A, Gillberg C, Palm A, Hagberg B. Elevated CSF glutamate in Rett syndrome. Neuropediatrics 1992; 23: 212-213.

121. Lappalainen R, Riikonen RS. High levels of cerebrospinal fluid glutamate in Rett syndrome. Pediatr Neurol 1996; 15: 213-216.

122. Uldall P, Hansen FJ, Tonnby B. Lamotrigine in Rett syndrome. Neuropediatrics 1993; 24: 339-340.

123. Stenbom Y, Tonnby B, Hagberg G. Lamotrigine in Rett syndrome: treatment experience from a pilot study. Eur Child Adolesc Psychiatry 1998; 7: 49-52.

124. Giordano L, Capovilla G, Beccaria F, et al. LTG therapy in 5 patients with Rett syndrome and epilepsy with the onset in the first 24 months of age. Bollettino-Lega Italiana Contra L'Epilessia 1998; 102-103: 151-152.

125. McDonald JW, Johnston MV. Physiological and pathophysiological roles of excitatory amino acids during central nervous system development. Brain Res Rev 1990; 15: 41-70.

126. Blue ME, Naidu S, Johnston MV. Development of amino acid receptors in frontal cortex from girls with Rett syndrome. Ann Neurol 1999; 45: 541-545.
127. Langlais PJ, Walsh FX, Bird ED, Levy HL. Cerebrospinal fluid neurotransmitter metabolites in neurologically normal infants and children. Pediatrics 1985; 75: 580-586.

128. Blue ME, Naidu S, Johnston MV. Altered development of glutamate and GABAreceptors in the basal ganglia of girls with Rett syndrome. Exp Neurol 1999; 156: 345-352.

129. Satoi M, Matsuishi T, Yamada S, et al. Decreased cerebrospinal fluid levels of B-phenylethylamine in patients with Rett syndrome. Ann Neurol 2000; 47: 801-803.

130. Casanova MF, Naidu S, Goldberg T, et al. Quantitative magnetic resonance imaging in Rett syndrome. J Neuropsychiatry 1991; 3: 366-372.

131. Murakami JW, Courchesne E, Haas RH, et al. Cerebellar and cerebral abnormalities in Rett syndrome: a quantitative MR analysis. AJR Am J Roentgenol 1992; 159: 177-183.

132. Reiss AL, Faruque F, Naidu S, et al. Neuroanatomy of Rett syndrome: a volumetric imaging study. Ann Neurol 1993; 34: 227-234.

133. Subramaniam B, Naidu S, Reiss AL. Neuroanatomy in Rett syndrome: cerebral cortex and posterior fossa. Neurology 1997; 48: 399-407.

134. Nielsen JB, Toft PB, Reske-Nielsen E, et al. Cerebral magnetic resonance spectroscopy in Rett syndrome. Failure to detect mitochondrial disorder. Brain Dev 1993; 15: 107-112.

135. Hanefeld F, Christen HJ, Holzbach U, et al. Cerebral proton magnetic resonance spectroscopy in Rett syndrome. Neuropediatrics 1995; 26: 126-127.

136. Hashimoto T, Kawano N, Fukuda K, et al. Proton magnetic resonance spectroscopy of the brain in 3 cases of Rett syndrome: comparison with autism and normal controls. Acta Neurol Scand 1998; 98: 8-14.

137. Pan JW, Lane JB, Hetherington H, Percy AK. Rett syndrome: ${ }^{1} \mathrm{H}$ spectroscopic imaging at 4.1 Tesla. J Child Neurol 1999;14:524-528.

138. Horská A, Naidu S, Herskovits EH, et al. Quantitative ${ }^{1} \mathrm{H}$ MR spectroscopic imaging in early Rett syndrome. Neurology 2000; 54: 715-722

139. Nielsen JB, Friberg L, Lou H, et al. Immature pattern of brain activity in Rett syndrome. Arch Neurol 1990; 47: 982-986.

140. Lappalainen R, Liewendahl K, Sainio K, et al. Brain perfusion SPECT and EEG findings in Rett syndrome. Acta Neurol Scand 1997; 95: 44-50.

141. Bjure J, Uvebrant P, Vestergren E, Hagberg B. Regional cerebral blood flow abnormalities in Rett syndrome. Eur Child Adolesc Psychiatry 1997; 6(Suppl 1): 64-66.

142. Burroni L, Aucone AM, Volterrani D, et al. Brain perfusion abnormalities in Rett syndrome: a qualitative and quantitative SPECT study with ${ }^{99} \mathrm{Tc}(\mathrm{m})-\mathrm{ECD}$. Nucl Med Commun 1997; 18: 527-534.

143. Yoshikawa H, Fueki N, Suzuki H, et al. Cerebral blood flow and oxygen metabolism in Rett syndrome. J Child Neurol 1991;6: 237-242.

144. Harris JC, Wong DF, Wagner HN, et al. Positron emission tomographic study of $\mathrm{D}_{2}$ dopamine receptor binding and CSF biogenic amine metabolites in Rett syndrome. Am J Med Genet 1986; 24(Suppl 1): 201-210.

145. Snow BJ, Tooyama I, McGeer EG, et al. Human positron emission tomographic $\left[{ }^{18} \mathrm{~F}\right]$ fluorodopa studies correlate with dopamine cell counts and levels. Ann Neurol 1993; 34: 324-330.

146. Pate BD, Kawamata T, Yamada T, et al. Correlation of striatal fluorodopa uptake in the MPTP monkey with dopaminergic indices. Ann Neurol 1993; 34: 331-338.

147. Trebossen R, Bendriem B, Ribeiro MJ, et al. Validation of the three-dimensional acquisition mode in Positron Emission Tomography for quantitation of $\left[{ }^{18} \mathrm{~F}\right]$ fluoro-Dopa uptake in human striata. J Cereb Blood Flow Metab 1998; 18: 951-959.

148. Pietrzyk U, Herholz K, Fink G, et al. An interactive technique for three-dimensional image registration: validation for PET, SPECT, MRI and CTbrain studies. J Nucl Med 1994; 35: 2011-2018.

149. Wong DF, Ricaurte G, Gründer G, et al. Dopamine transporter changes in neuropsychiatric disorders. Adv Pharmacol 1998, 42: 219-223.

150. Chiron C, Bultreau C, Loch C, et al. Dopaminergic $\mathrm{D}_{2}$ receptor 
SPECTimaging in Rett syndrome: increase of specific binding in striatum. J Nucl Med 1993; 34: 1717-1721.

151. Naidu S, Kaufmann W, Abrams M, et al. Neuroimaging studies in Rett syndrome. World Congress on Rett Syndrome 2000. Plenary Lecture-IV:6.

152. Cordes M, Snow BJ, Cooper S, et al. Age-dependent decline of nigrostriatal dopaminergic function: a positron emission tomographic study of grandparents and their grandchildren. Ann Neurol 1994; 36: 667-670.

153. Nomura Y. Neurophysiology of Rett syndrome. World Congress on Rett Syndrome 2000. Plenary Lecture-II: 4.

154. Filipek PA, Accardo PJ, Ashwal S, et al. Screening and diagnosis of autism: report of the Quality Standards Subcommittee of the American Academy of Neurology and the Child Neurology Society. Neurology 2000; 55: 468-479.
155. Chiron C, Leboyer M, Leon F, et al. SPECT of the brain in childhood autism: evidence for a lack of normal hemispheric asymmetry. Dev Med Child Neurol 1995; 37: 849-860.

156. Chugani DC, Muzik O, Behen M, et al. Developmental changes in brain serotonin synthesis capacity in autistic and nonautistic children. Ann Neurol 1999; 45: 287-295.

157. Ellaway C, Buchholz T, Smith A, Leonard H, Christodoulou J. Rett syndrome: significant clinical overlap with Angelman syndrome but not with methylation status. J Child Neurol 1998; 13: 448451.

158. Budden SS. Management of Rett syndrome: a ten-year experience. Neuropediatrics 1995; 26: 75-77.

159. Budden SS. Rett syndrome: habilitation and management reviewed. Eur Child Adolesc Psychiatry 1997; 6(Suppl 1): 103107. 